\title{
How is Mathematics taught in Pandemic Era? An exploratory Study in Primary School in Indonesia
}

\author{
Tria Mardiana ${ }^{1}$, Puji Rahmawati ${ }^{2}$, Indiati ${ }^{3}$, Galih Istiningsih ${ }^{4}$ \\ \{triamardiana@ummgl.ac.id ${ }^{1}$ \} \\ PGSD, Universitas Muhamamdiyah Magelang, Indonesia ${ }^{1,2,3,4}$
}

\begin{abstract}
The purpose of this study is to describe the learning process of Mathematics during the Covid-19 pandemic. This goal is to be achieved because learning mathematics is a fairly complex subject. This research uses qualitative research. This research applies an exploratory case study aims to get information about how mathematics learning during the covid-19 pandemic. The data collection method in this research using semi-structured interviews that were made primary data. Meanwhile, secondary data is in the form of studies References. Interviews were conducted in a semi-structured manner. Interviews were carried out by giving questionnaires and confirmation by telephone or WhatsApp. Telephone interviews were conducted for confirmation and in-depth interviews. Interviews conducted by telephone are intended to support physical distancing which is applied to prevent transmission of Covid-19. The mathematics learning process carried out by teachers during the Covid-19 pandemic consisted of online and offline processes. Teachers are still trying to do various ways to create maximum mathematics learning in elementary schools during the Covid-19 pandemic. In implementing mathematics learning activities during the Covid-19 pandemic, teachers did not only apply one method, but combined more than one method..
\end{abstract}

Keywords: mathematics learning; learning methods; covid-19

\section{Introduction}

At this time the whole world has been hit by a pandemic, all aspects of life are affected, including the education system. Almost all countries have closed access to face-to-face learning in classrooms, including Indonesia. One way to break the chain of spreading covid-19 is by limiting community interaction which is applied by the term physical distancing [1] [2]. The Indonesian government has also closed access to face-to-face learning since March 16, 2020 to reduce the current spread of the Covid-19 virus. All learning activities become distance learning with teachers and students in their respective homes [3]. Covid-19 is one of the pandemics that has been going on for a long time in Indonesia. Based on information obtained from the PHEOC of the Indonesian Ministry of Health, on June 11, 2020, the number of confirmed positive cases totaled 35,295, 12,636 recovered cases, and 2000 died [4].

Learning activities during the Covid-19 pandemic are carried out in various ways so that the substance of the material is conveyed. The current pandemic condition requires educators, in this case, teachers to innovate in changing face-to-face learning patterns into face-to-face learning patterns [5]. The existence of physical restrictions causes student learning activities to be carried out at home. The impact of these conditions requires students to be able to learn independently. Learning independence is one of the important things in a learning process [6]. 
However, there are many factors that influence the success of students in the learning process at home [7]. This is because the teacher's control in learning at home cannot be maximized as during direct learning in class.

Particularly in assigning assignments, the thing that needs to be considered is that in its implementation, it must be monitoring and mentoring by teachers [8]. Apart from teachers, the role of parents is very important in accompanying children's learning at home, where learning is currently taking place online [9]. Learning assistance is carried out not only in certain subjects, but mentoring needs to be done in all lessons. One of the subjects that got a big impact from various aspects during the Covid-19 pandemic is Mathematics. Moreover, one of the current problems is that there are still many students who think mathematics is a difficult subject [1].

Learning mathematics is one of the contents in thematic learning in elementary schools. Basically, mathematics learning has abstract characteristics, and its concepts and principles are tiered [10]. Relating to mathematics teaching in schools, the program or activity which will be done should also refer to the regulation. In the current curriculum (Curriculum 2013), since 2018 the teaching of mathematics for higher elementary school grades (grade 4, 5, and 6) there is an additional portion (other than the thematic lesson) for $6 \times 35$ minutes in a week. This will allow the mathematics lesson to be done completely but still comprehensive [11]. Learning mathematics that is abstract and difficult makes students tend to experience difficulties in understanding mathematical concepts [12]. For this reason, even before the Covid-19 pandemic, Mathematics already had many challenges, both in terms of material, students, and teaching methods. With the covid-19 pandemic which limits access to interaction, of course, it adds to the challenge, especially in delivering material so that it can be absorbed optimally. Due to these conditions, the purpose of this study is to provide information about the ways teachers teach mathematics during the Covid-19 pandemic. With this information, it is hoped that teachers will have many references and methods for teaching mathematics during the Covid-19 pandemic.

\section{Method}

This research uses qualitative research. The design used is an exploratory case study which aims to obtain information about how mathematics is taught during the Covid-19 pandemic. This research is limited to the elementary school level. The data collection method in this study used semi-structured interviews which were used as primary data. Meanwhile, secondary data is in the form of literature study. Interviews were conducted in a semi-structured manner. Interviews were conducted by providing questionnaires and confirmation by telephone or Whatsapp. Telephone interviews were conducted for confirmation and in-depth interviews so that the data obtained was more complete. Interviews conducted by telephone are intended to support physical distancing which is applied to prevent transmission of Covid-19.

The research subjects used 184 respondents. These respondents are teachers who teach Mathematics at the elementary school level with a grade level of 1-6. The interview guide used in this study is to confirm the methods used by the teacher in teaching Mathematics during Covid-19, as well as the reasons for choosing the method used by the teacher. to teach Math during covid-19. 


\section{Results and Discussion}

The research begins by sending a questionnaire to teachers who teach at the elementary school level, specifically on learning mathematics. The questionnaire data was also confirmed by telephone or whatsapp. This is to validate data and add information in the field, regarding Mathematics learning carried out by teachers during the Covid-19 pandemic. Table 1 is the classification of the respondent's data used in this study.

Table 1. Data on Primary School Mathematics Teacher Respondents

\begin{tabular}{|c|c|c|}
\hline No & Class & Teachers \\
\hline 1 & I & 20 \\
2 & II & 45 \\
3 & III & 38 \\
4 & IV & 34 \\
5 & V & 29 \\
6 & VI & 18 \\
\hline \multicolumn{2}{|c|}{ Total } & 184 \\
\hline
\end{tabular}

Source: Processed Data, 2020

From 184 respondents, data is presented in table 2 regarding the acquisition of information on Mathematics learning methods carried out by teachers during the Covid-19 pandemic. The data obtained exceeds the number of respondents because each respondent applies more than one type of method when learning mathematics. Table 2 show data regarding the methods used by teachers in learning Mathematics during the Covid-19.

Table 2. Data regarding the methods used by teachers in learning Mathematics during the Covid-19

\begin{tabular}{|c|l|c|}
\hline No & \multicolumn{1}{|c|}{ The Method Used } & Teachers \\
\hline 1 & Voice Note & 54 \\
2 & Sending Video & 69 \\
3 & Whatsapp Group & 184 \\
4 & Youtube & 96 \\
5 & Direct visit & 41 \\
6 & Zoom Meeting & 56 \\
7 & Google Meet & 38 \\
8 & Google Classroom & 102 \\
9 & Google Form & 180 \\
10 & Quizizz & 23 \\
11 & Taking assignments to school & 184 \\
12 & Television & 19 \\
13 & Radio Streaming & 18 \\
\hline \multicolumn{2}{|c|}{ Total } & $\mathbf{1 0 6 4}$ \\
\hline
\end{tabular}

Figure 1 is data regarding the methods used by teachers while teaching Mathematics during the Covid-19 Pandemic in diagrammatic form. Through the data in the form of a diagram, we can observe more clearly the distribution of the information data obtained. In Figure 1, additional information can be described regarding the classification of mathematics learning activities that are in the online category and the offline category. The online category of methods consists of Quizizz, Television, Radio Streaming, Voice Note, Sending Video, Google Form, 
Whatsapp Group, Google Classroom, Google Meet, Zoom Meeting, and Youtube. The offline method category consists of direct visits and taking assignments to school

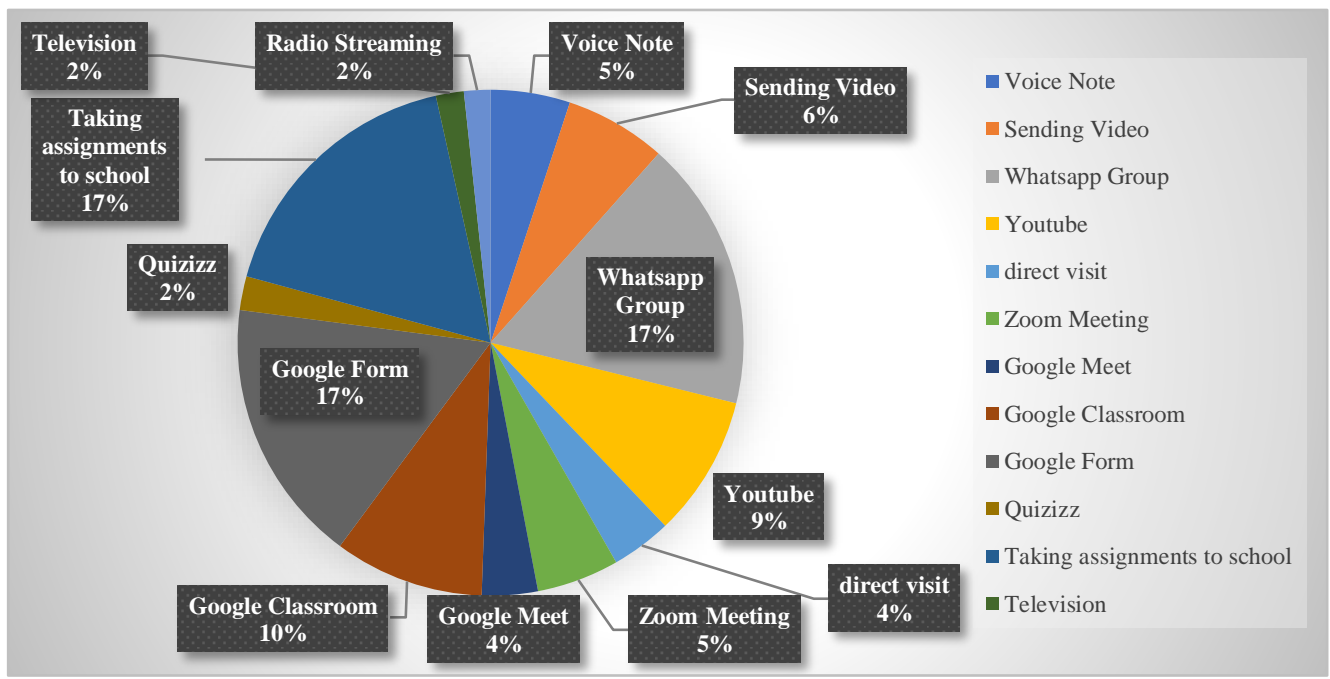

Fig. 1. Diagram of the Results of Data Acquisition Learning Methods Used by teachers in Mathematics learning during the Covid-19 pandemic

To see the comparison of online and offline learning during the Covid-19 pandemic, we can observe in Figure 2. Figure 2 provides information that for the selection of methods, online learning methods are much greater than offline methods. The online method consists of 11 types, while the offline method consists of 2 ways. In addition to that information, online learning has been widely promoted to replace traditional face-to-face learning during the COVID-19 pandemic to maintain young children's learning and play at home [13].

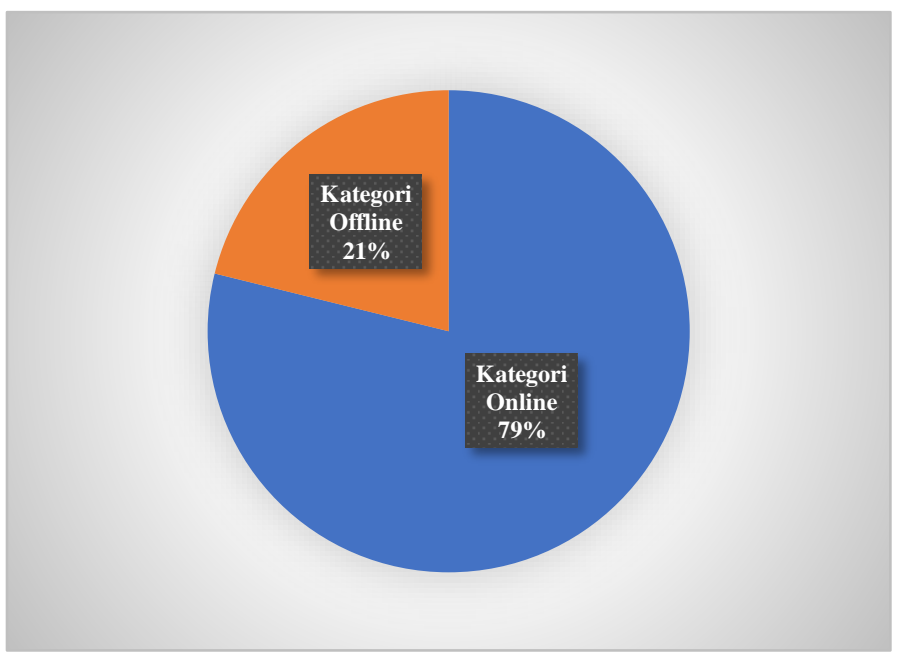

Fig. 2. Data on differences in the number of online and offline categories 
In choosing a method, of course the teacher also has a reason or background. This is so that the teaching process can run optimally, and mistakes or deficiencies in teaching can be minimized. The background of the teacher's choice of methods is presented in Table 3. This data exceeds the number of respondents because many respondents chose more than one background in choosing the method. This is important information that every teacher really thinks about the concept of learning that is being carried out. This is of course so that teaching activities can run optimally and according to the needs of students.

Table 3. Teacher background data in choosing the method chosen when learning mathematics

\begin{tabular}{|c|l|c|}
\hline No & \multicolumn{1}{|c|}{ Reason for Selection } & Voter \\
\hline 1 & Easy to apply & 184 \\
2 & Can greet students & 51 \\
3 & Cost effective & 180 \\
4 & Preparation doesn't take long & 160 \\
5 & Helping students who don't have devices & 120 \\
6 & Can organize evaluations & 58 \\
\hline
\end{tabular}

In Figure 3, data is presented regarding the distribution of teacher background information in choosing mathematics learning methods during the Covid-19 pandemic.

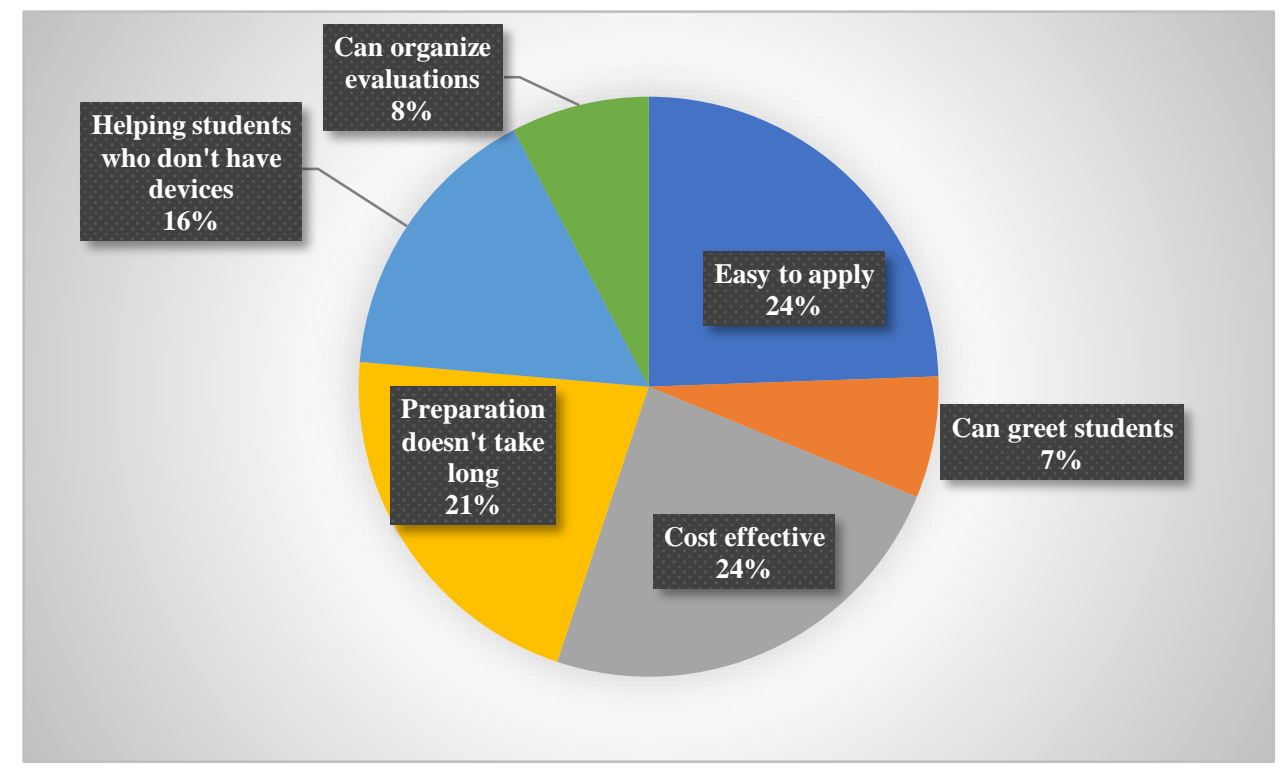

Fig. 3. Tea cher background data in choosing the method chosen when learning mathematics in the form of a diagram

During the in-depth interviews conducted with respondents, some important information was obtained regarding the learning process of mathematics during the Covid-19 pandemic. The first information, learning mathematics when Covid-19 requires much more preparation than before Covid-19. The process carried out by the teacher often combines more than 1 method so that the material can be absorbed optimally. This condition requires teachers to be more creative 
in applying mathematics learning methods during the Covid-19 pandemic, both online and offline.

The second information is the emergence of data on the dishonesty of student work results. When the teacher gives assignments online, the results often score high. Whereas when it was confirmed to students, when schools provided face-to-face time with very limited duration, students showed very different results. The students who had high scores, when confirmed regarding the material received did not show the same level of understanding. Conditions like this require teachers to always remind parents that learning assistance at home does not end up doing assignments, tasks are still done by children themselves through guidance from parents so that children understand the tasks being done.

Third, the appropriate method of teaching mathematics cannot be determined from one or two choices. During implementation, teachers must continue to innovate to find effective ways that can be used in mathematics learning activities. Student conditions, geographic conditions where students live, conditions of parental education, grade level, are some of the reasons that not all schools can apply the same method in implementing mathematics learning during Covid19. However, teachers remain the main determinant of the direction of mathematics learning during the Covid-19 pandemic.

\section{Conclusion}

The mathematics learning process carried out by teachers during the Covid-19 pandemic consisted of online and offline processes. Online learning on mathematics consists of Quizizz, Television, Radio Streaming, Voice Note, Sending Video, Google Form, Whatsapp Group, Google Classroom, Google Meet, Zoom Meeting, and Youtube. Meanwhile, offline learning consists of direct visits and taking assignments to school. Teachers are still trying to do various ways to create maximum mathematics learning in elementary schools during the Covid-19 pandemic. In implementing mathematics learning activities during the Covid-19 pandemic, teachers did not only apply one method, but combined more than one method. The results of this study are useful for mathematics teachers in determining appropriate learning methods during the Covid-19 pandemic.

\section{Acknowledgement}

Researchers would like to thank the University of Muhammadiyah Magelang and the team at LP3M Unimma for providing education, direction, and evaluation for the sustainability of this research process.

\section{References}

[1] Mustakim, "Efektivitas Pembelajaran Daring Menggunakan Media Online Selama Pandemi Covid19 Pada Mata Pelajaran Matematika," Al asma J. Islam. Educ., vol. 2, no. 1, pp. 1-12, 2020.

[2] C. A. Azlan et al., "Teaching and learning of postgraduate medical physics using Internet-based elearning during the COVID-19 pandemic - A case study from Malaysia," Phys. Medica, vol. 80, no. September, pp. 10-16, 2020, doi: 10.1016/j.ejmp.2020.10.002. 
[3] A. N. Muthy and H. Pujiastuti, "Analisis media pembelajaran e-learning melalui pemanfaatan teknologi dalam pembelajaran matematika di rumah sebagai dampak 2019-nCoV," J. Math Educ. Nusant. Wahana Publ. Karya Tulis Ilm. di Bid. Pendidik. Mat., vol. 6, no. 1, pp. 94-103, 2020, doi: 10.29407/jmen.v6i1.14356.

[4] B. Santoso, "Prosach: Sebagai Acuan Pembelajaran Matematika Dengan Menggunakan Platform Digital Di Masa Pandemik Covid-19," LINEAR J. Math. Educ., vol. 1, no. 1, pp. 57-63, 2020, [Online]. Available: http://e-journal.metrouniv.ac.id/index.php/linear/article/view/2224.

[5] A. Anugrahana, "Hambatan, Solusi dan Harapan: Pembelajaran Daring Selama Masa Pandemi Covid-19 Oleh Guru Sekolah Dasar," Sch. J. Pendidik. dan Kebud., vol. 10, no. 3, pp. 282-289, 2020.

[6] A. S. Handayani and I. Ariyanti, "Kemandirian Belajar Matematika Siswa SMP Disaat Pandemi Covid-19," in UrbanGreen Proceeding: Konferensi Nasional Pendidikan I, 2020, pp. 6-10, [Online]. Available: https://urbangreen.co.id/proceeding/index.php/library/article/view/2.

[7] T. T. Sari and A. H. Cahyono, "Pengembangan E-Learning Berbasis Android 'Fun Math' Sebagai Alternatif Belajar Matematika Di Tengah Pandemi," J. Cendekia J. Pendidik. Mat., vol. 04, no. 02, pp. 1283-1299, 2020.

[8] I. Setyorini, "Pandemi Covid-19 Dan Online Leraning: Apakah Berpengaruh Terhadap Proses Pembelajaran Pada Kurikulum 13?,” J. Ind. Eng. Manag. Res., vol. 01, no. Juni, pp. 95-102, 2020, doi: https://doi.org/10.7777/jiemar.v1il.

[9] A. Risalah, W. Ibad, L. Maghfiroh, M. I. Azza, S. A. Cahyani, and Z. A. Ulfayati, "Dampak Pandemi Covid-19 Terhadap Kegiatan Belajar Mengajar Di MI/SD (Studi KBM Berbasis Daring Bagi Guru dan Siswa)," JIEES J. Islam. Educ. Elem. Sch., vol. 1, no. 1, pp. 10-16, 2020, doi: 10.47400/jiees.v1i1.5.

[10] Wiryanto, "Proses Pembelajaran Matematika Di Sekolah Dasar Di Tengah Pandemi Covid-19," J. Rev. Pendidik. Dasar J. Kaji. Pendidik. dan Has. Pendidik., vol. 6, no. 2, 2020.

[11] N. Primasatya and I. F. Imron, "Analysis of Student Needs of The Mathematics Club (MC) as a CoCurricular Activities as an Effort to Grow Up 4C Skills," J. Math Educ. Nusant., vol. 6, no. 2, pp. 215-223, 2020, [Online]. Available: http://repository.polnep.ac.id/xmlui/bitstream/handle/123456789/354/03-YANI R.pdf?sequence=1.

[12] H. Rosiyanti, A. F. Adriansyah, R. Widiyasari, and N. S. Dewi, "Analisis Persepsi Peserta didik Terhadap Video Pembelajaran Matematika Kelas VIII Pada Masa Pandemi," in Seminar Nasional Penelitian LPPM UMJ, 2020, pp. 1-11.

[13] C. Dong, S. Cao, and H. Li, "Young children's online learning during COVID-19 pandemic: Chinese parents' beliefs and attitudes," Child. Youth Serv. Rev., vol. 118, no. August, pp. 1-9, 2020, doi: 10.1016/j.childyouth.2020.105440. 